SOME THOUGHTS ON SOCIO-ECONOMIC RIGHTS

ISSN 1727-3781

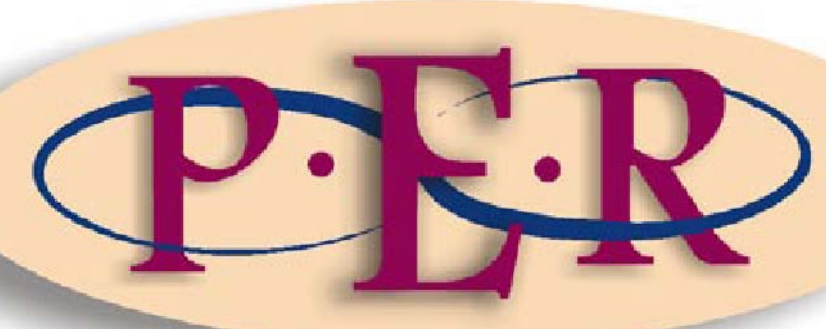

2003 VOLUME 6 No 2 


\section{SOME THOUGHTS ON SOCIO-ECONOMIC RIGHTS}

Prof GE Devenish

\section{$1 \quad$ INTRODUCTION}

One of the manifest differences between the Bill of Rights in the interim and the 1996 Constitutions is the more comprehensive treatment of social and economic rights in the latter. ${ }^{1}$ In addition to the social and economic rights of children contained in section 28(1)(c), education in section 29 and detained persons' rights in section 35(2)(e), Chapter 2 of the 1996 Constitution encapsulates "an entirely new set of rights not foreshadowed in the interim Constitution". ${ }^{2}$ These relate essentially to housing rights, set out in section 26 , and rights protecting health care services, food, water and social security contained in section 27. Certain other provisions also contain socio-economic rights. So, for example, section 25(5) redistribution of land, section 28, children's rights, section 29, education, section $35(2)$ (c), the right to a legal practitioner, section 35(2)(e), detainees rights to adequate accommodation, nutrition, reading material and medical treatment.

\section{JURISPRUDENTIAL BACKGROUND}

The extent to which, if any, socio-economic rights should be protected has been and continues to be a matter of perplexing jurisprudential controversy in South Africa. The ANC, by virtue of its history as liberation movement, has in the past demonstrated a fervent commitment to socialism, ${ }^{4}$ and consequently it favoured extensive state involvement in the economy and the inclusion of the whole panoply of socio-economic rights in the Constitution such as freedom from hunger, the right to shelter, health services and employment.

1 Davis, Cheadle an Haysom Fundamental Rights in the Constitution 342 et seq.

Ibid.

3 The view of the South African Chamber of Mines and the South African Chamber of Business was that socio-economic rights should not be included in the Bill of Rights as they were unattainable and the were "bad for business": see "Sosio-ekonomiese regte en die grondwet" Constitutional Talk 11 August to 25 August no 10,6.

4 See Riordan "The Freedom Charter and the nationalisation of industry" in Polley (ed) The Freedom Charter and the Future (1998) 4751. 
The presence of enforceable socio-economic rights in the Constitution means that the philosophy of the Constitution reflects social democracy rather pure liberalism. The purpose of the Constitution is not merely to protect extant rights, but also to empower disadvantaged persons and to contribute to the amelioration of social evils such as poverty, illiteracy and homelessness. In the discourse of human rights, socio-economic rights are commonly referred to as 'second generation' rights, to distinguish them from so-called political and civil rights, referred to as first generation rights. The Constitution requires that the state realize certain educational, housing and social security objectives, which cannot be merely left to the mechanism of the free market for fulfilment.

The underlying political philosophy for second generation rights is one of social justice involving policies of human compassion, sharing and caring. Furthermore, socio-economic rights are not unimportant, the are not merely of secondary importance. The Teheran Conference on Human Rights, organised under the auspices of the United Nations, emphasized the importance of economic, social and cultural rights, and as 'n result declared:

In our day political rights without social rights, justice under law without social justice, and political democracy without economic democracy no longer have any true meaning.

In more recent times, international human rights discourse has recognised 'third generation' rights, such as the right to a safe environment, the right to development and the right to information. The realization of both second and third generation human rights requires a very careful and judicious balancing of the interests of the individual against those of the community as a whole. Social justice and welfare are institutionalized as rights to which citizens are entitled as part of the democratic body politic created by the Constitution. The constitutional welfare state is not a passive one, but an active that must of necessity intervene in the economy of a country to ensure that basic needs are met.

5 The Final Act of the International Conference on Human Rights, Teheran 1968. See UN Doc A/Cont 32/41

6 Newman and Weissbrodt International Human Rights: Law, Policy and Process (1996) 81 as quoted by Motala and Ramaphosa Constitutional Law 391. 